\title{
Progress in the 21st century: a Roadmap for the Ecological Society
} of Japan

Received: 6 January 2014 / Accepted: 28 February 2014 / Published online: 23 March 2014

(C) The Author(s) 2014. This article is published with open access at Springerlink.com

\begin{abstract}
The primary goal of the 60th anniversary symposium of the Ecological Society of Japan (ESJ) was to re-examine the role of the Society. The first of five lectures, "Development of Long-term Ecological Research in Japan," discussed the increasingly important role of long-term and networked research studies. Ecological research in Asia faces many challenges, because Asia features natural and anthropogenic landscapes with highly diverse ecosystems. "Developing Strategies of the Ecological Society of Japan for Worldwide Societies of Ecology with Special Reference to Strategies for Asia",
\end{abstract}

T. Enoki $(\bowtie)$

Shiiba Research Forest, Kyushu University, 949 Okawachi, Shiiba, Miyazaki 883-0402, Japan

E-mail: enoki@forest.kyushu-u.ac.jp

Tel.: + 81-983-381005

Fax: $+81-983-381004$

T. Nakashizuka

Department of Environmental Life Sciences, Tohoku University, Sendai 980-8577, Japan

S. Nakano

Center for Ecological Research, Kyoto University,

Otsu 520-2113, Japan

T. Miki

Institute of Oceanography, National Taiwan University,

Taipei 10617, Taiwan

Y.-P. Lin

Department of Bioenvironmental Systems Engineering,

National Taiwan University, Taipei 10617, Taiwan

M. Nakaoka

Akkeshi Marine Station, Field Science Center for Northern

Biosphere, Hokkaido University, Akkeshi 088-1113, Japan

E. Mizumachi

Institute for Integrated Cell-Material Sciences (WPI-iCeMS),

Kyoto University, Kyoto 606-8501, Japan

H. Shibata

Field Science Center for Northern Biosphere,

Hokkaido University, Sapporo 060-0809, Japan emphasized the role of ESJ in promoting ecological research and outreach in Asia. Ecosystem sustainability is a key issue in both the theory and practice of ecosystem management. A framework concept of an environmental and biodiversity cycle was proposed in the session "Linking Community and Ecosystem Dynamics" for understanding the mechanisms driving the sustainability of ecosystems. Ecosystem services are essential aspects of land use and conservation planning and management. "Integrating Models of Ecosystem Services and Land Use Changes" reviewed recently-developed models that simulate patterns of land-use change and analyze its effects on ecosystem services and also recommended future directions for collaboration among researchers. "Disaster Resilience and Coastal Ecology" highlighted the contributions of ecologists to evaluating the resilience of damaged coastal ecosystems and provided sound proposals to local communities and governments for rehabilitation plans. The past achievements and future directions of ESJ were discussed by the panelists and the audience in "Past and Future of the Ecological Society of Japan."

Keywords Asia Community and ecosystem dynamics - Disaster resilience $\cdot$ Land use change · Long-term ecological research

\section{Introduction}

The Ecological Society of Japan (ESJ) was established in 1953 to promote research and education in all aspects of ecology. ESJ celebrated its 60th anniversary in 2013. How the society envisions itself has changed over time. In addition to promoting research in the basic field of ecology and related sciences, ESJ has come to play other roles. These include contributing to finding solutions to social and environmental problems, such as the loss of biodiversity, and addressing global climate change. These goals are often pursued by establishing close relationships with various types of international and 
domestic organization (governmental, industrial, and non-profit).

The 50th anniversary meeting of ESJ that was held in Tsukuba, Japan, in 2003 provided an opportunity to highlight the following three roles of ESJ: (1) to promote ecological research at large spatial and temporal scales; (2) to contribute not only to conservation of natural ecosystems but also to the recovery and rehabilitation of damaged or lost ecosystems; and (3) to promote international activities, especially within the East Asian region. The 50th anniversary meeting of ESJ prompted the establishment of two new ESJ committees, the Committee of Large-Scale and Long-Term Ecology and the Committee of Ecosystem Management, and promoted connections with the East Asian Federation of Ecological Societies (EAFES). In 2003, EAFES was established collaboratively by the ecological societies of China, Japan, and Korea to promote ecological science in East Asia.

A symposium titled "Progress in the 21st Century: A Roadmap of the Ecological Society of Japan" was held during the 60th annual meeting of ESJ in Shizuoka, Japan, on 6 March, 2013. This symposium was organized to evaluate the past activities and future roles of ESJ. The symposium consisted of five lectures and a general discussion. The themes of the five lectures were based on the achievements of the 50th anniversary meeting. The first two lectures mainly reviewed the achievements of ESJ over the past decades, whereas the last three focused on the current and future directions of the society's activities. However, the selected topics did not cover every challenge facing ESJ. This paper summarizes the symposium, following the sequence of the lectures and ending with the final panel discussion. The symposium consisted of two parts: (1) an overview of long-term ecological research (LTER) in Japan and the international role of ESJ; and (2) a review of recent ecological research.

The overview addressed two topics. The first topic introduced the history of LTER in Japan since the conclusion of the International Biological Program (IBP) of 1964-1974. LTER has long been recognized as providing important data and knowledge; LTER networks in the United States (US LTER) and internationally (ILTER) have been established to build a global network (Kim 2006). This section of the meeting described the relatively long gap between the establishment of LTER and the initiation of an effective LTER network in Japan. It also emphasized the current and future need for ecologists in Japan to participate in several new projects associated with LTER. The second topic described the international efforts of ESJ since the conclusion of the IBP. The section reviewed past and current strategies of the ESJ to promote worldwide research projects and to establish international organizations and societies designed to encourage ecological research.

The second part of the symposium was divided into three topics related to advances in the theory, modeling, and practices of ecosystem management. The first topic introduced one of the most important subjects in ecology today on a global scale: elucidating the links between community and ecosystem ecology. The discussion on the sustainability of ecosystems addressed a key issue for both the theory and practice of ecosystem management. The section provided a framework concept of an environmental and biodiversity cycle to provide a better understanding of ecosystem sustainability. The second topic reviewed recently-developed models that simulate the patterns and consequences of land-use and land-cover change. Ecosystem services are essential aspects of land use and conservation planning and management. The section described various models and emphasized that developing integrated models of ecosystem services and land-use changes is essential. The third topic addressed the Great East Japan Earthquake of 11 March, 2011, described the resilience of coastal ecosystems in light of this and other disasters, and integrated other topics related to coastal ecology. Scientific knowledge related to ecology helps people evaluate how catastrophic disturbances damage ecosystems and emphasizes ecosystem resilience. Such information allows ecologists to make sound proposals to local communities, stakeholders, and decision-makers for improving rehabilitation plans. Finally, a summary of the general discussion held at the symposium is given in the last part of this review, with emphasis on some proposals for future activities of ESJ.

\section{History and the roles of ESJ}

Development of long-term ecological research in Japan

Long-term ecological research is important because it elucidates (1) processes that occur slowly, (2) the effects of rare and episodic events, (3) processes with large fluctuations, and (4) processes with complicated interactions. Recently, LTER has also been expected to provide scientific findings to help solve global environmental issues. The foundations of LTER were laid in the early 1980s, when the IBP was completed (Table 1). The IBP established a basis for large-scale ecosystem studies and clarified factors involved in biological production as well as in matter and energy cycling in various types of ecosystem. The program also established a number of research sites with the potential to integrate more research and/or comparative studies. US scientists established the US-LTER network in 1980 to extend IBP activities and include discussions on the significance of long-term research (Franklin 1987). US-LTER initially established 17 domestic research sites, and then expanded into an international and global network upon the creation of the International LTER (ILTER) in 1993.

In contrast, the research sites established during the IBP in Japan were not directly integrated into a system similar to the US-LTER. Some of the sites were not 
Table 1 History of long-term ecological studies and related issues since 1970

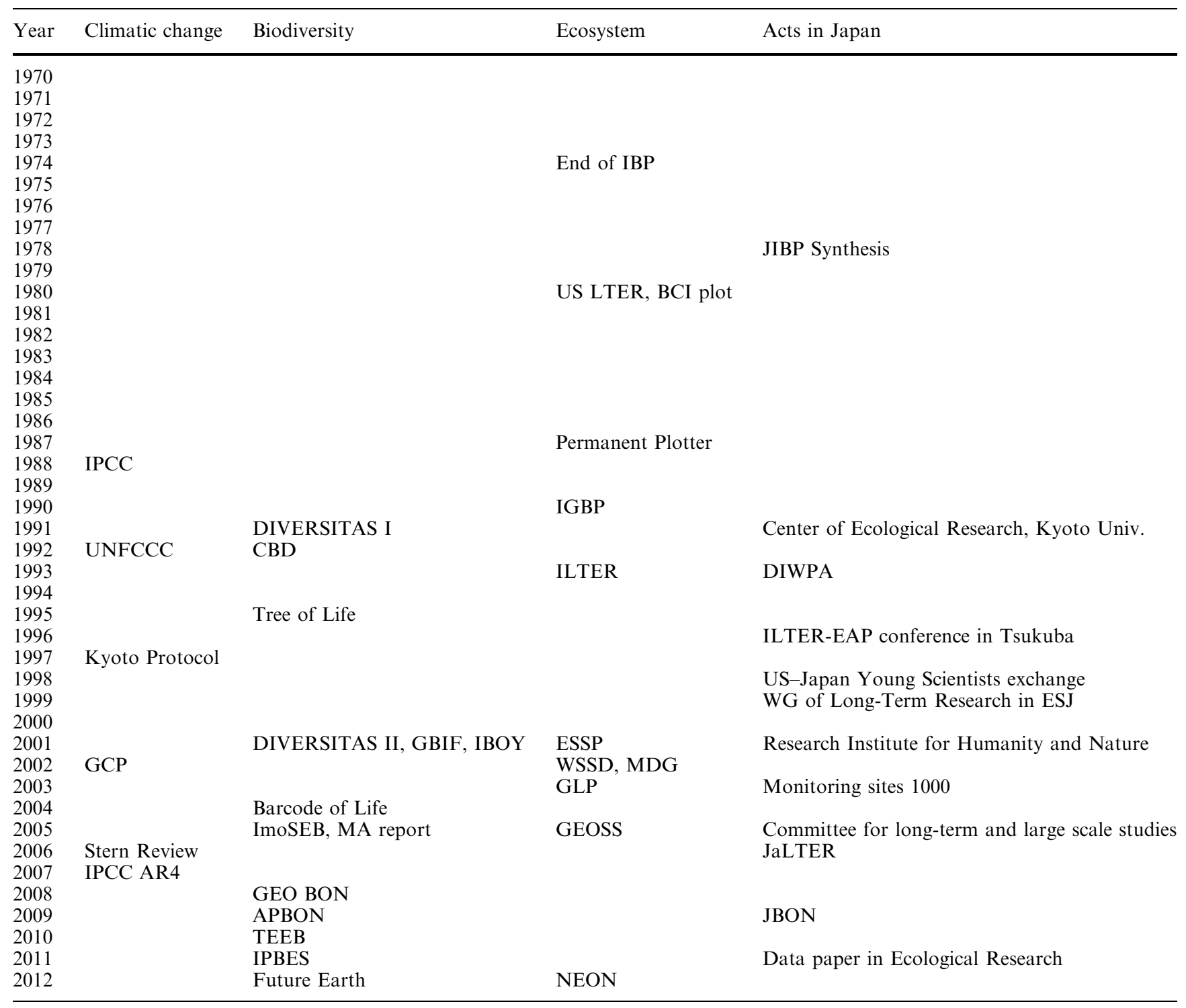

maintained, although a small number have been preserved through the personal efforts of individuals. In some cases, valuable data were lost. The IBP studies in Japan made outstanding contributions to documenting productivity and nutrient cycling in various ecosystems, and the results were found to be very useful internationally (Kira et al. 1978). However, the research foci of ecologists have shifted over time, and the IBP framework was not successfully implemented in subsequent decades. Thus, a rather long gap exists from the conception to the establishment of long-term ecological studies and an associated network in Japan.

Since the early 1990s, global environmental issues such as climate change and biodiversity loss have shifted the focus of many ecological studies. Site-based ecological research is important to these issues. The International Geosphere-Biosphere Programme (IGBP) and DIVERSITAS, both of which were established to pro- mote international collaboration in studies involving biodiversity, commenced operations in 1990 and 1993, respectively. Long-term and networked studies seem to be very effective in answering questions related to these issues. For instance, the studies on Barro Colorado Island (BCI), Panama, which were initiated by the Smithsonian Tropical Research Institute, provided considerable new insight on biodiversity in tropical forests (Hubbell and Foster 1983). The institute also started to establish a network of studies in various regions of the tropics (Table 2).

In response to these research trends, some long-term study activities also emerged in Japan (Nakashizuka 1991) and a voluntary network was established among them. Members of the network have met several times and collaborated on a publication describing the importance of long-term and networked studies (Nakashizuka 2001). Also, they have operated an exchange 
Table 2 Abbreviations and URLs of referenced organizations, projects, and networks

\begin{tabular}{|c|c|c|}
\hline Name & Abbreviation & URL \\
\hline Asia-Pacific Biodiversity Observation Network & AP-BON & http://www.esabii.org/ap-bon/index.html \\
\hline Barcode of Life & Barcode of Life & http://www.barcodeoflife.org \\
\hline Convention on Biological Diversity & CBD & http://www.cbd.int \\
\hline DIVERSITAS & DIVERSITAS & http://www.diversitas-international.org/ \\
\hline DIVERSITAS in the Western Pacific and Asia & DIWPA & http://diwpa.ecology.kyoto-u.ac.jp/index.html \\
\hline East Asian Federation of Ecological Societies & EAFES & http://www.e-eafes.org \\
\hline Ecological Society of Japan & ESJ & http://www.esj.ne.jp \\
\hline Earth System Science Partnership & ESSP & http://www.essp.org \\
\hline Future Earth & FE & http://www.icsu.org/future-earth \\
\hline Global Biodiversity Information Facility & GBIF & http://www.gbif.org \\
\hline Global Carbon Project & GCP & http://www.globalcarbonproject.org \\
\hline Group on Earth Observations Biodiversity Observation Network & GEO BON & http://www.earthobservations.org/geobon.shtml \\
\hline Global Earth Observation System of Systems & GEOSS & http://www.epa.gov/geoss/ \\
\hline Global Land Project & GLP & http://www.globallandproject.org \\
\hline International Biodiversity Observation Year & IBOY & \\
\hline International Biological Program & IBP & $\begin{array}{l}\text { http://www.nasonline.org/about-nas/history/ } \\
\text { archives/collections/ibp-1964-1974-1.html }\end{array}$ \\
\hline International Council of Science & ICSU & http://www.icsu.org/ \\
\hline International Geosphere-Biosphere Programme & IGBP & http://www.essp.org/?id=22 \\
\hline International Geophysical Year (IGY)"” & IGY & http://www.nas.edu/history/igy/ \\
\hline International Human Dimensions Programme & IHDP & http://www.ihdp.unu.edu/ \\
\hline International Long-Term Ecological Research Network & ILTER & http://www.ilternet.edu/ \\
\hline International Mechanism of Scientific Expertise on Biodiversity & ImoSEB & \\
\hline Intergovernmental Platform on Biodiversity \& Ecosystem Services & IPBES & http://www.ipbes.net \\
\hline Intergovernmental Panel on Climate Change & IPCC & http://www.ipcc.ch/index.htm \\
\hline Japan Long-Term Ecological Research Network & JaLTER & http://www.jalter.org/ \\
\hline Millennium Development Goals & MDG & http://www.un.org/millenniumgoals/ \\
\hline National Ecological Observatory Network & NEON & http://www.neoninc.org/ \\
\hline Economics of Ecosystems and Biodiversity & TEEB & http://www.teebweb.org \\
\hline Tree of Life web project & Tree of Life & http://tolweb.org/tree/ \\
\hline United Nations Framework on Climate Change & UFCCC & http://unfccc.int/2860.php \\
\hline US Long-Term Ecological Research Network & US LTER & http://www.lternet.edu/ \\
\hline World Climate Research Programme & WCRP & http://www.wcrp-climate.org/ \\
\hline World Summit on Sustainable Development & WSSD & http://www.who.int/wssd/en/ \\
\hline
\end{tabular}

program between US-LTER and young Japanese scientists. ESJ also created a working group to promote LTER in 1999 and in 2005 promoted the group into a committee. In 2003, the Japanese Ministry of the Environment began ecosystem monitoring activities in Japan (Monitoring Site 1000) and the ecologist group decided to collaborate with this effort. Also, the Global Earth Observation System of Systems (GEOSS) was established, and Japanese scientists played key roles in planning its activities. Based on new requirements and policies, LTER scientists were expected to make a significant contribution. Supported by these activities, Japan LTER (JaLTER) was officially established in 2006 and joined the ILTER network in 2007 (Enoki et al. 2007), 27 years after US-LTER was established. JaLTER has 20 Core and 36 Associate research sites (in 2012) and has become one of the most active ILTER networks.

The role of long-term and networked research studies has become increasingly important. The Group on Earth Observations Biodiversity Observation Network (GEOBON) was established under GEOSS, with the ILTER sites serving as key observation points in this program. Some new issues are also emerging. In 2012, the US initiated another, even larger activity, the National Ecological Observatory Network (NEON), to provide answers to global environmental problems. Thus, the activities of LTER and NEON complement each other somewhat; LTER sites study processes to integrate findings from the bottom up, while NEON will assess large-scale change based on systematic monitoring. Another trend is to enlarge research projects and make them more multi-disciplinary. In 2011, the International Council of Science (ICSU) reformed the conventional framework of international science programs into the Future Earth framework. This program integrates natural sciences with social and human sciences. Japanese ecologists are expected to be involved with such international concepts and projects more actively than previously. In this case, the framework of the LTER network must be used to its full capacity, although some new perspectives and mechanisms must be added to enable integrated multi-disciplinary studies.

Developing strategies for ESJ related to worldwide societies of ecology with special reference to strategies for Asia

ESJ was established in 1953 . The 1950s were a time when researchers studying environmental sciences engaged in intense international collaboration. In 1951, when Japan 


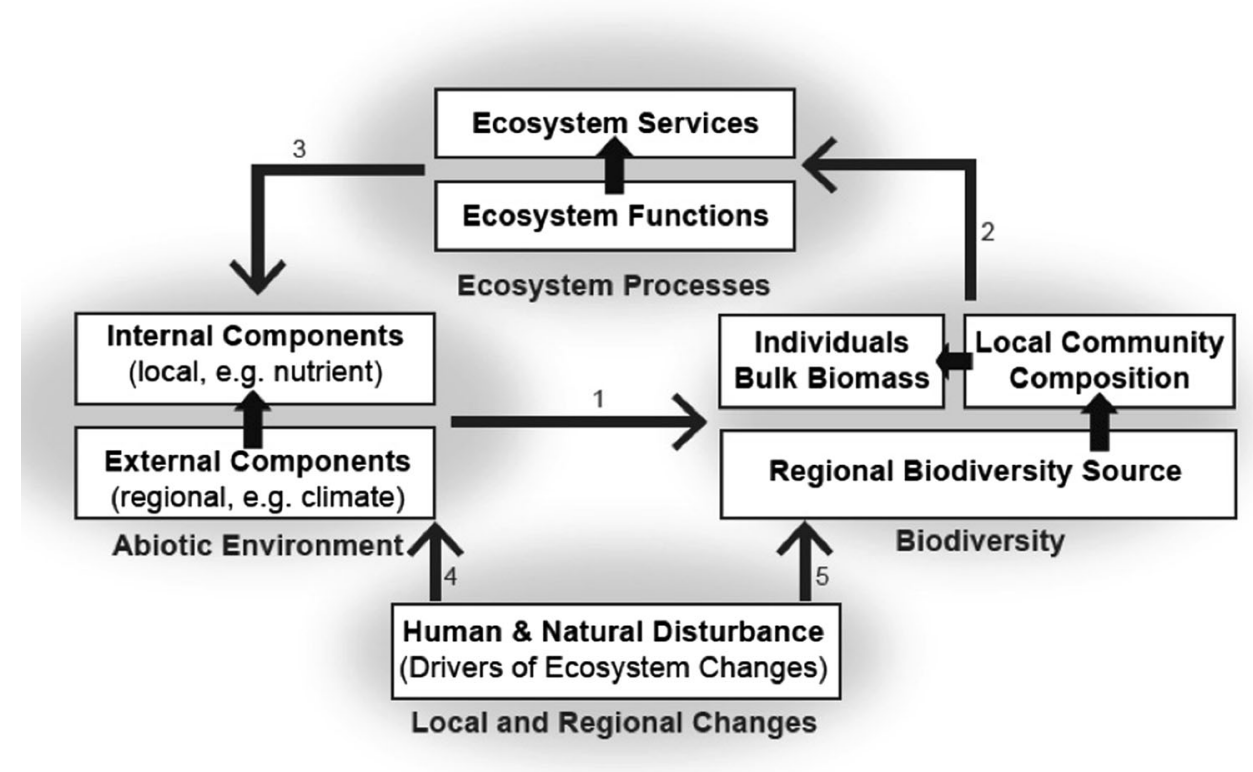

Fig. 1 Environment-biodiversity cycle. The abiotic environment consists of (1) internal components such as soil nutrients, which are rapidly modified by local ecosystem activity, and (2) external components such as climate, which may change slowly. Biodiversity has three important components: local species composition;

had not yet become independent (prior to the effective date of the San Francisco Treaty) researchers working in the environmental sciences proposed The International Geophysical Year (IGY), with a comprehensive series of global geophysical activities. During the final stage of the IGY in 1957 and 1958, 67 countries participated. Under the worldwide trend for international collaboration, ESJ initiated developmental strategies for the world starting in the 1960s. One of the main concerns for ESJ was biodiversity.

To promote the IBP, ESJ started to examine the foundation of the Joint Usage Center for freshwater biology, using Kyoto University's Otsu Hydrobiological Station (OHBS) as a basis (Center for Ecological Research 2011). This led the establishment of the Center for Ecological Research (CER), Kyoto University, by reorganizing the OHBS and the Plant Ecological Research Station in 1991 when DIVERSITAS was launched (Center for Ecological Research 2011). In 1992, the research program SymBiosphere: Ecological Complexity for Promoting Biodiversity proposed by CER was adopted by IUBS, SCOPE, and UNESCO (Kawanabe et al. 1993; Kawanabe 1996); this encouraged ESJ to take the lead in biodiversity research Japan (Kawanabe 1996). Thus, ESJ cultivated a closer connection to DIVERSITAS, launching DIVERSITAS in the Western Pacific and Asian regions (DIWPA) in 1993 (Center for Ecological Research 2011).

Why concentrate on the Western Pacific and Asia? In October 1992, Prof. Kawanabe and his colleagues held an international symposium at La Selva, Costa Rica, bulk quantity, such as total biomass or forest size; and the regional pool of biodiversity. (3) Ecosystem processes include both ecosystem functions and services. Drivers of ecosystem changes appear at both local and regional scales

and discussed the most important regions of the world for biodiversity research where financial and manpower sources were limited (Kawanabe 1996). Interestingly, they identified the unique ecosystems of the Western Pacific and Asia as being most important, including the terrestrial Green Belt from Siberia to New Zealand and the marine Blue Belt along its eastern border (Kawanabe 1996). Places with high primary production were expected to have high biological diversity, so those researchers eventually decided to focus on the biodiversity in that region (Kawanabe 1996).

DIWPA has organized many international meetings, built capacity through an international field biology course, organized the International Observation Year of Biodiversity (DIWPA-IBOY) in 2001, published several books (nine volumes as of May 2013), and publishes newsletters (28 as of May 2013) (DIWPA Newsletter $1995,2003,2004)$.

In 2003, the East Asian Federation of Ecological Societies (EAFES) was formed through the collaboration of ecological societies in China, Japan (ESJ), and Korea to promote ecological science in East Asia. EAFES plans symposia, meetings, joint research projects, and other activities to contribute to the development ecological science and ecological societies in this region. The three national ecological societies take turns organizing the joint EAFES Congress at least once every 2 years; five congresses have been held thus far.

One of ESJ's important recent activities related to Asian biodiversity is the Asia-Pacific Biodiversity Observation Network (AP-BON), which was launched in 
2009 and collaborates with GEO-BON. GEO-BON collects and analyzes data on the status of and trends in the world's biodiversity, with special attention paid to ecosystems, species, genes, and ecosystem services. APBON has organized several international workshops (Yahara et al. 2012) and published a book on biodiversity research in Asia (Nakano et al. 2012).

ESJ has been supporting the startup of Future Earth (Asian Conservation Ecology 2013), because implementation of a symbiotic society will strengthen the links between human beings and ecosystems. Future Earth will also concentrate on the links between human beings and biodiversity, one of the important challenges for ecologists.

Biodiversity is a global resource of tremendous value to the present and future well-being of humanity. However, anthropogenic threats to species and ecosystems have never been as serious as they are today. We hope ESJ will continue its activities in support of the sustainable use of biodiversity and ecosystems to create a symbiotic society.

\section{Landscape ecology and ecosystem services}

Linking community and ecosystem dynamics: the role of competition

A fundamental question in ecology today is the origin of ecosystem sustainability, although it has not often been addressed (e.g., Cropp and Gabric 2002). If the origin of life on Earth does not automatically imply the establishment of a sustainable ecosystem, there should be undiscovered mechanisms at the levels above the single individual and population in support of the long-term persistence of ecosystems. Elucidating this issue will not only contribute to establishing a fundamental theory of ecology but also provide conceptual and practical solutions for sustainable management of human-dominated ecosystems.

A conceptual framework that integrates the interactions among major components in ecosystems (Chapin et al. 2000, 2009; Miki 2009) has been developed in the last two decades to improve our understanding of the mechanisms producing sustainable ecosystems. Here, we present an environment-biodiversity cycle in a simplified ecosystem (Fig. 1) that describes (1) endogenous feedbacks among the abiotic environment, the biotic community (biodiversity), and ecosystem processes and (2) the modification of these endogenous feedbacks by human and natural disturbances. By addressing the role of competition, we first review three major questions that have been extensively investigated. Second, we recommend a few ideas for future research from the community ecology perspective.

The first question is: what determines the structure of a community and local biodiversity (see arrows 1 and 5 in Fig. 1)? Competition (and other ecological interactions) and disturbance have been identified as the determinants in population and community ecology (Connell 1978; Tilman 1980; Interlandi and Kilham 2001; Molino and Sabatier 2001). However, in other fields (e.g., biogeography and macroecology), species composition has been understood as an additive sum of individual species preferences and adaptations to local environments (Brown 1995; Gaston 2000; Pearson and Dawson 2003). The second question is: what are the patterns and mechanisms of the relationship between biodiversity and ecosystem function (see arrow 2 in Fig. 1). At a local scale, the relationship is characterized by (1) the selection effect, (2) functional complementarity and insurance, and (3) functional redundancy (Loreau et al. 2001; Hooper et al. 2005; Reich et al. 2012). Competition is responsible for all three components by determining (1) species abundance distribution, (2) niche differentiation, and (3) niche overlap. The third question is: what are the consequences of the feedback process between local components of the abiotic environment (e.g., soil nutrients), the entire community (e.g., total biomass of key players such as plants), and ecosystem functions (e.g., nutrient cycling) (see arrows 1, 2, and 3 in Fig. 1). The direction of feedback determines ecosystem resilience and the likelihood of state shifts among multiple steady states (Scheffer and Carpenter 2003; Folke et al. 2004; Chapin et al. 2009). Competition is sometimes, but not always, involved in the feedback loop (e.g., competition for resources and space among functional types, Berendse 1994; McCook 1999).

From a basis in community ecology, we propose three research directions for a better mechanistic understanding the environment-biodiversity cycle. The first direction would be integrating the processes involved in these three questions to help researchers understand the entire environment-biodiversity cycle. We should incorporate biodiversity into studies of ecological resilience (the third question) by considering the impact of local environmental conditions on local biodiversity (the first question) and the impact of local biodiversity on the local environment via ecosystem processes (the second question). For example, the strength and direction of local control by the community of the abiotic environment (through their ecosystem functions) is not only determined by dominant functional traits (e.g., of plants) but also modified by biodiversity and functional traits in other functional groups (e.g., soil decomposers) (Naeem et al. 2000; Duffy et al. 2007; Miki et al. 2010; Miki 2012). The second direction is to develop our understanding of large-scale community ecology concepts. The roles of competition and other ecological interactions in creating community structure variation and in changing the biodiversity gradient at large spatial scales still remain unclear, but 'global' community ecology is one of several emerging fields in global change biology (Araújo and Luoto 2007; Brook 2009; Gilman et al. 2010). As for the third direction, the development of a quantitative model based on community ecology is necessary; such a model could quantitatively predict the impacts of human 
activities (Drivers of ecosystem changes, MA 2005) on biodiversity and the impacts of biodiversity changes on ecosystem processes (e.g., Miki et al. 2013). For these new research questions and directions, large ecological datasets will be increasingly important. Therefore, longterm and large-scale ecological observations and experiments will play central roles in community ecology in the next 10 years.

Integrating models of ecosystem services and land use changes

Land-use and land-cover (LULC) change may affect ecosystem function. Ecologists often study and quantify the impacts of land-use changes on ecosystems and their functions. Numerous land-use models, including stochastic, optimization, dynamic process-based simulation, and empirical models, have been developed to simulate the patterns and consequences of LULC for various purposes. The models are classified into different categories. For instance, Parker et al. (2003) designated land-use models as Equation-based, Econometric, Statistical, System, Expert, and Evolutionary models as well as Cellular Automata and Agent-based Models and Hybrid Models.

The conversion of land use and its effects (CLUEs) is a hybrid land-use model that simulates land-use changes using empirically quantified relationships between land use and its driving factors in dynamic land-use modeling (Verburg et al. 2002; Verburg and Veldkamp 2004; Lin et al. 2007). In CLUEs land-use modeling, the allocation of each land-use type is based on a combination of empirical and spatial analyses along with dynamic modeling (Verburg et al. 2002; Lin et al. 2007). However, quantifying all of the potential interactions between the different land uses and drivers in a logistic regression model is difficult for three reasons: (1) the lack of a thorough understanding of all the factors involved; (2) insufficient information about the interactions; and (3) restrictions on the functional form of the logistic regression model (Lambin and Geist 2006; Lin et al. 2011). Artificial neural networks (ANNs) consider any nonlinear complex relationship between the drivers and land uses (Pijanowski et al. 2002, 2005; Dai et al. 2005) without additional information or functional forms and have been applied in land-use change modeling (e.g., Pijanowski et al. 2005; Almeida et al. 2008; Liu and Seto 2008).

The Slope, Land use, Excluded land, Urban extent, Transportation, and Hillshading (SLEUTH) model combines an urban growth model with the land-cover change model developed by Clarke (Clarke 1997; Lin et al. 2008), which generates multiple simulations of the growth of cities using Monte Carlo routines (Lin et al. 2008). SLEUTH is a bottom-up simulation model that uses adaptive cellular automata to simulate the growth and environmental changes of cities. Moreover, in urban growth module, urban dynamics are simulated using the growth rules of SLEUTH (Claggett et al. 2004). Agentbased modeling (ABM) is widely used to simulate landuse changes that result from variations in individual decisions and actions (Matthews et al. 2007; Parker et al. 2003; Robinson et al. 2007; Valbuena et al. 2010). Because ABM defines different decision-making units or agents, it can model the interactions between humans and natural systems (Valbuena et al. 2010) and simulate land-use changes. However, SLEUTH and ABM can be classified as bottom-up models. In addition to models designed to explore possible land-use change under plausible scenarios in the near future, policymakers determine the optimal land-use configurations in terms of costs and effects using various tools (Loonen et al. 2007; Lin et al. 2009). A land-use model based on a spatial pattern optimization could be used to complement and support landscape conservation design and planning (Duh and Brown 2005; Loonen et al. 2007; Lin et al. 2009).

Ecosystem services are the benefits that humans derive from ecosystems (MA 2005). The Millennium Ecosystem Assessment Report (2005) categorized ecosystem services into four groups: supporting, provisioning, regulating, and cultural services. Recently, the importance of research into ecosystem services has been widely recognized. The mapping of ecosystem services is regarded as a key element in having institutions and decision-making bodies recognize the value of ecosystem services (Daily and Matson 2008; Burkhard et al. 2009). In recent years, many scientists have developed approaches for mapping ecosystem services (e.g. Troy and Wilson 2006; Egoh et al. 2008; Naidoo et al. 2008; Burkhard et al. 2009; Nelson et al. 2009; Tallis and Polasky 2009).

Integrated Valuation of Ecosystem Services and Tradeoffs (InVEST) and Artificial Intelligence for Ecosystem Services (ARIES) are Geographical Information System (GIS)-based ecosystem services tools (Vigerstol and Aukema 2011) used to map ecosystem services across landscapes. InVEST 2.1 beta version was developed by Tallis et al. (2011). It comprises a suite of models that use LULC patterns to estimate the levels and economic values of ecosystem services, biodiversity conservation, and the market values of commodities provided by the landscape (Nelson et al. 2009). InVEST models are spatially explicit, use maps as information sources, and produce maps as outputs (Tallis et al. 2011). ARIES (Villa et al. 2009) is a web-based tool used to map ecosystem services. It allows users to evaluate trade-offs among ecosystem services and to identify stakeholders who may benefit from services in a study area (Vigerstol and Aukema 2011). Moreover, ARIES identifies relationships between user input data and ecosystem service values using probabilistic Bayesian networks. To map beneficiaries, ARIES can often be run with a single spatial data layer or simple GIS operations rather than Bayesian networks (Bagstad et al. 2011). However, there is a dearth of spatially-explicit values of ecosystem services across landscapes that might inform 
land-use and management decisions (Balmford et al. 2002; MA 2005; Nelson et al. 2009), so further studies are needed.

Recently, a multi-disciplinary research community has identified the goods and services provided by ecosystems in sites scattered across the world (Nelson and Daily 2010). By understanding how changes in LULC and land management cause changes in ecosystem services across a landscape, researchers (e.g., Nelson and Daily 2010) can design and implement policy interventions to improve ecosystem service values and marketed economic returns on the landscape. However, LULC models have been widely used in modeling LULC changes. Ecosystem service modeling is just beginning to be applied in the policy arena (Nelson and Daily 2010). GIS is a potential tool that can be used to model, analyze, and map ecosystem services and LULC for land management and conservation planning. For instance, InVEST and ARIES are both GIS-based models. Thus, integrating models of land use and ecosystem services in a GIS-based platform provides essential information used in land-use and conservation planning and management; this method can simulate land-use changes and their effects on ecosystems and ecosystem services or functions.

\section{Disaster resilience and coastal ecology}

The coastal areas of northeastern Japan were heavily damaged by the 11 March, 2011, mega-earthquake and tsunami. We realized how vulnerable human society, even in highly-developed countries, is to catastrophic disasters that occur on time scales of hundreds to thousands of years. How can we, as ecologists, contribute to enhancing the resilience of damaged coastal ecosystems and help local societies recover after such a disaster? The major goals of natural science are to quantitatively assess and evaluate the impacts of such catastrophic events on ecosystems and to estimate the ecosystem resilience. Based on the scientific data collected after such disasters, we can then make sound proposals to local communities, stakeholders, and decision-makers to improve rehabilitation plans.

One of the difficulties in effectively assessing the impact of catastrophic events such as tsunamis is that quantitative data on ecosystems are not always available prior to the disturbances because they are unpredictable. Long-term monitoring data of biodiversity and ecosystems collected prior to such events, if they exist, allow evaluation of the impact through before/after comparisons (Whanpetch et al. 2010). A long-term ecosystem monitoring program, entitled Monitoring Sites 1000, covers three coastal sites on the Sanriku (northeastern Tohoku) coast that were heavily affected by the tsunami. By continuing the same type of monitoring after the tsunami, we could quantitatively examine its impact on these sites. The tsunami's impact was remarkably variable among habitat types. A tidal flat in Fukushima and two seagrass beds in Iwate were heavily impacted by the tsunami, with a large decrease in species diversity and in the abundance of major organisms, whereas the diversity and abundance of an algal community in Miyagi did not change greatly after the tsunami. The level of impact varied even within a single seagrass bed in areas with different depth gradients and topographical settings. Large differences within a small spatial scale were also reported in the impact assessment of the 2004 tsunami along the Andaman Sea coast of Thailand (Whanpetch et al. 2010). Similar tsunami impact assessments have been ongoing by various marine scientists and fisheries researchers who have been studying the areas since before the disaster happened (Urabe et al. 2013; Takami et al. 2013). Mate analysis incorporating these individual studies across a large spatial extent and diverse environmental gradients provide promising ways to understand general characteristics of how the tsunami's impacts and subsequent recovery processes varied.

A further challenge to ecologists is to develop a way to effectively use our science-based knowledge for decision making for and by coastal human communities, such as designing rehabilitation plans to maintain coastal biodiversity and effectively restoring marine resources. Some ongoing attempts include plans to develop marine protected areas (and their potential candidates), to enhance recovery of severely-damaged habitats using surviving local populations, and to establish new management plans for fisheries and aquaculture that are reasonably sustainable over the long run.

A recent highlight in ecology is that the ecosystem connectivity among different types of adjacent habitat, such as between forest and river or between terrestrial and marine ecosystems, is seen to play an important role in structuring the biological community and material flows in each system (Polis and Hurd 1996; Nakano and Murakami 2001). Incorporating the concept of connectivity can contribute to better rehabilitation planning in damaged coastal areas. In most coastal areas of Japan, including the Sanriku regions, natural connectivity among terrestrial, river, and marine ecosystems had been substantially lost since the mid-20th century with the expansion of industrial activities such as reclamation and the construction of ports and embankments along the coastline (Shikita and Koarai 1997). The tsunami damaged these man-made structures, which ironically led to the recovery of natural connectivity in some areas. Scientists, environmental administrators, and some local citizens are working together to incorporate these newly recovered ecosystem links into rehabilitation plans to enhance the resilience of coastal ecosystems and their services; for example, some guidelines established by the Ministry of the Environment illustrate this technique (2013). Our next challenge is to consider how we can incorporate these guidelines into actual rehabilitation plans at each local site. Discussion with local stakeholders, decision makers, and other interested persons is required for fairness in the development of coastal 
rehabilitation plans that consider the conservation of biodiversity and sustainable use of ecosystem services in damaged areas.

In conclusion, ecologists can contribute to enhancing the disaster resilience of areas affected by the tsunami in a variety of ways, ranging from a general understanding of the tsunami's impacts on marine ecosystems to the use of new science-based knowledge for rehabilitation activities at various levels (local, regional, and national). The achievements are worthwhile not only for increased resilience in disaster-damaged regions in northeastern Japan but also for other regions of the world where catastrophic events will occur in the future.

\section{Past and future of ESJ; sketches of questionnaires and discussions during the 60th anniversary symposium}

During the discussion session of the 60th anniversary symposium, the past achievements and future directions of ESJ were discussed by the panelists and audience. To facilitate this discussion, the organizing committee collected various opinions from ESJ members and used a web-based questionnaire distributed with the meeting announcement via the ESJ mailing lists to ensure that a diversity of perspectives were considered. Sixty-three ESJ members responded to the questionnaires between 19 December, 2012, and 4 March, 2013. The questionnaire asked the following four questions:

Q1. What major discoveries and significant progress have been made in ecology in Japan during the past decade?

Q2. What research area in ecology in Japan is expected to be emphasized in the coming decade?

Q3. What is the global role of the Ecological Society of Japan?

Q4. Do you believe national policies and the needs of the public affect your research currently?

The responses to the first question highlighted a wide diversity of opinions addressing many aspects of ecology in Japan. The organizing committee of the symposium used a few representative comments to facilitate discussion during the meeting. Some comments addressed long-term advances in ecological research (e.g., Enoki et al. 2007; Ohte et al. 2012), including the improved understanding of non-steady state phenomena. Progress made in the production and use of analytical tools for mega-ecological data was also emphasized (Cornwell et al. 2008; Ishihara et al. 2011). Also, some responders noted the rising popularity of "biodiversity" as a common keyword for the ecological community and general public during the last decade (Fujikura et al. 2010; Larigauderie et al. 2012; Vihervaara et al. 2013). Others commented on an abundance of project-based largescale ecological research studies compared with fewer small-scale studies conducted by individuals (DIVERSITAS; IGBP; Kohyama et al. 2007).

During the symposium's discussion, some panelists mentioned that ecologists in Japan are dealing with a wider variety of ecological data, including the long-term monitoring of biogeophysical parameters as powerful indicators of environmental conditions and ecosystem functions (e.g. Ishihara et al. 2011; Iken et al. 2010; Yoshida et al. 2006). The other panelists noted that we have developed and applied various new analytical technologies to ecological research, such as molecular biology (Azuma et al. 2006; Okubo and Sugiyama 2009), remote sensing (Hiura 2005; Yamaji et al. 2008; Nagai et al. 2010), GIS (Ileva et al. 2009; Yoshida and Noguchi 2009), and numerical modeling (Sato et al. 2007; Katsuyama et al. 2009; Miki et al. 2010).

Regarding the future direction of ESJ, some responses to the questionnaire emphasized the need for further progress on biodiversity conservation, ecosystem management, and ecosystem rehabilitation with Asiawide perspectives to contribute not only to ecological interests but also to societal needs (Nakano et al. 2012). Others pointed to basic and pure ecological studies, such as taxonomy, natural history, physiology, and the clarification of mechanisms within ecosystems, as important research topics. Some insisted that unique research themes that do more than simply copy those in the United States and Europe should be critical to ecological studies within the ESJ and also in the international research arena. The panelists also addressed the need to ensure that future ecological studies in Japan cover diverse research areas (i.e., basic and applied research and collaborative- and individual-based projects) with unique research questions, hypotheses, and topics. One panelist emphasized the need for ESJ and Japanese ecologists to be more engaged in international networks (e.g., Shibata and Bourgeron 2011) by sharing data and analytical tools to create new concepts and findings.

Contributions by the audience at the symposium included the needs to improve the educational system, establish core stations for integrated ecosystem-biodiversity-climate change research, help young scientists become involved in global research trends such as Future Earth, and appeal to multidisciplinary and cross-site research findings for the general public and society. The ESJ members provided suggestions, comments, and opinions on how national policies and the needs of the public have been affecting their research. Many challenges lie ahead for ecological research and outreach, especially in Asia, with its highly diverse ecosystems that include natural and humanmodified landscapes. Useful tools are now available that improve the resolution and accuracy of data collected and analyzed by ecologists. The activities of the individual are of supreme importance both for the pure science of ecology and for the application of ecological principles. In addition, the importance of the roles of ESJ was recognized, as was the importance of the relationships between ESJ and the research studies of its members. We hope the symposium will be a landmark of interactive development among ESJ members, ESJ, and all people concerned. 
Acknowledgments The 60th anniversary symposium was organized to accommodate a project of the Committee for the Future Society of ESJ. We thank Profs. K. Kitayama, T. Yahara, and an anonymous researcher for providing presentation materials and information about DIVERSITAS, DIWPA, and AP-BON. We also thank K. Watanabe, T. Suzuki, A. Dazai, Y. Sakanishi, K. Yokoi, M. Nakagawa, and N. Sato for their help with ecological monitoring. This study was partially supported by Environment Research Funds (B-0910 and S-9) of the Ministry of the Environment, grants by Tohoku Ecosystem-Associated Marine Sciences, Mitsui Co. Ltd. the Research Fund for Evaluation of Carbon Absorption Ability of Coastal Ecosystems by the Fisheries Research Agency, and grantsin-aids from the Ministry of Education, Culture, Sports, Science and Technology, Japan (No. 21241055, 24405012).

Open Access This article is distributed under the terms of the Creative Commons Attribution License which permits any use, distribution, and reproduction in any medium, provided the original author(s) and the source are credited.

\section{References}

Almeida CM, Gleriani JM, Castejon EF, Soares-Filho BS (2008) Using neural networks and cellular automata for modelling intra-urban land-use dynamics. Int J Geogr Info Sci 22:943-963

Araújo MB, Luoto M (2007) The importance of biotic interactions for modeling species distributions under climate change. Global Ecol Biogeogr 16:743-753

Asian Conservation Ecology (2013) http://www.conservatione cology.asia/sympSemi/sympOld/symposium 20130423

Azuma N, Ogata K, Kikuchi T, Higashi S (2006) Phylogeography of Asian weaver ants, Oecophylla smaragdina. Ecol Res $21: 126-136$

Bagstad KJ, Villa F, Johnson GW, Voigt B (2011) ARIES-Artificial Intelligence for Ecosystem Services: a guide to models and data, version 1.0. ARIES report series 1

Balmford A, Bruner A, Cooper P, Costanza R, Farber S, Green RE, Jenkins M, Jefferiss P, Jessamy V, Madden J, Munro K, Myers N, Naeem S, Paavola J, Rayment M, Rosendo S, Roughgarden J, Trumper K, Turner RK (2002) Economic reasons for conserving wild nature. Science 297:950-953

Berendse F (1994) Litter decomposability - a neglected component of plant fitness. J Ecol 82:187-190

Brook BW (2009) Global warming tugs at trophic interactions. J Anim Ecol 78:1-3

Brown JH (1995) Macroecology. The University of Chicago Press, Chicago

Burkhard B, Kroll F, Müller F, Windhorst W (2009) Landscapes' capacities to provide ecosystem services - a concept for landcover based assessments. Landsc Online 15:1-22

Center for Ecological Research, Kyoto University (2011) 20th Anniversary Special Issue, Center for Ecological Research, Kyoto University

Chapin FS III, Zavaleta ES, Eviner VT, Naylor RL, Vitousek PM, Reynolds HL, Hooper DU, Lavorel S, Sala OS, Hobbie SE, Mack MC, Diaz S (2000) Consequences of changing biodiversity. Nature 405:234-242

Chapin FS III, Folke C, Kafinas GP (2009) A framework for understanding change. In: Chapin FS III, Kofina GP, Folke C (eds) Principles of ecosystem stewardship: resilience-based natural resource management in a changing world. Springer, New York, pp 3-28

Claggett PR, Jantz CA, Goetz SJ, Bisland C (2004) Assessing development pressure in the Chesapeake Bay Watershed: an evaluation of two land-use change models. Environ Monit Assess 94:129-146

Clarke KC (1997) Land transition modeling with deltatrons. In: Proceedings of the land use modeling conference, Sioux Falls, SD

Connell JH (1978) Diversity in tropical rain forests and coral reefs. Science 199:1302-1310
Cornwell WK, Cornelissen JHC, Amatangelo K, Dorrepaal E, Eviner VT, Godoy O, Hobbie SE, Hoorens B, Kurokawa H, Pérez-Harguindeguy N, Quested HM, Santiago LS, Wardle DA, Wright IJ, Aerts R, Allison SD, Van Bodegom P, Brovkin V, Chatain A, Callaghan TV, Díaz S, Garnier E, Gurvich DE, Kazakou E, Klein JA, Read J, Reich PB, Soudzilovskaia NA, Vaieretti MV, Westoby M (2008) Plant species traits are the predominant control on litter decomposition rates within biomes worldwide. Ecol Lett 11:1065-1071

Cropp R, Gabric A (2002) Ecosystem adaptation: do ecosystems maximize resilience? Ecology 83:2019-2026

Dai E, Wu SH, Shi WZ (2005) Modeling change-pattern-value dynamics on land-use: an integrated GIS and artificial neural networks approach. Environ Assess 36:576-591

Daily GC, Matson PA (2008) Ecosystem services: from theory to implementation. Proc Natl Acad Sci USA 105:9455-9456

DIWPA News letter No. 1 (1995) http://diwpa.ecology.kyoto-u. ac.jp/publications.html

DIWPA News letter No. 17 (2003) http://diwpa.ecology.kyoto-u. ac.jp/publications.html

DIWPA News letter No. 18 (2004) http://diwpa.ecology.kyoto-u. ac.jp/publications.html

Duffy JE, Cardinale BJ, France KE, Mcintyre PB, Thébault E, Loreau M (2007) The functional role of biodiversity in ecosystems: incorporating trophic complexity. Ecol Lett 10:522-538

Duh JD, Brown DG (2005) Generating prescribed patterns in landscape models. In: Maguire DJ, Goodchild MF, Batty M (eds) GIS, spatial analysis and modeling. ESRI Press, New York, pp 423-444

Egoh B, Reyers B, Rouget M, Richardson DM, Le Maitre DC, van Jaarsveld AS (2008) Mapping ecosystem services for planning and management. Agric Ecosyst Environ 127:135-140

Enoki T, Shibata H, Hiura T, Nakashizuka T (2007) A beginning of LTER in Japan: approach from forest science. J Jpn For Soc 89:311-313 (in Japanese)

Folke C, Carpenter S, Walker B, Scheffer M, Elmqvist T, Gunderson L, Holling CS (2004) Regime shifts, resilience, and biodiversity in ecosystem management. Annu Rev Ecol Evol Syst 35:557-581

Franklin JF (1987) Importance and justification of long-term studies in ecology. In: Likens GE (ed) Long-term studies in ecology: approaches and alternatives. Springer, New York, pp 3-19

Fujikura K, Lindsay D, Kitazato H, Nishida S, Shirayama Y (2010) Marine biodiversity in Japanese waters. PLoS ONE 5:e11836. doi:10.1371/journal.pone.0011836

Gaston KJ (2000) Global patterns in biodiversity. Nature 405:220-227

Gilman SE, Urban MC, Tewksbury J, Gilchrist GW, Holt RD (2010) A framework for community interactions under climate change. Trends Ecol Evol 25:325-331

Hiura T (2005) Estimation of aboveground biomass and net biomass increment in a cool temperate forest on a landscape scale. Ecol Res 20:271-277

Hooper DU, Chapin FS III, Ewel JJ, Hector A, Inchausti P, Lavorel S, Lawton JH, Lodge DM, Loreau M, Naeem S, Schmid B, Setala H, Symstad AJ, Vandermeer J, Wardle DA (2005) Effects of biodiversity on ecosystem functioning: a consensus of current knowledge. Ecol Monogr 75:3-35

Hubbell S, Foster RB (1983) Diversity of canopy trees in a neotropical forest and implications for conservation. In: Sutton SL, Whitmore TC, Chadwick AC (eds) Tropical rain forest: ecology and management. Blackwell Scientific Publications, Oxford, pp 25-41

Iken K, Konar B, Benedetti-Cecchi L, Cruz-Motta JJ, Knowlton A, Pohle G, Mead A, Miloslavich P, Wong M, Trott T, Mieszkowska N, Riosmena-Rodriguez R, Airoldi L, Kimani E, Shirayama Y, Fraschetti SY, Ortiz-Touzet M, Silva A (2010) Large-scale spatial distribution patterns of echinoderms in nearshore rocky habitats. PLoS ONE 5:e13845. doi:10.1371/ journal.pone.0013845 
Ileva NY, Shibata H, Satoh F, Sasa K, Ueda H (2009) Relationship between the riverine nitrate-nitrogen concentration and the land use in the Teshio River watershed, North Japan. Sustain Sci 4:189-198

Interlandi SJ, Kilham SS (2001) Limiting resources and the regulation of diversity in phytoplankton communities. Ecology $82: 1270-1282$

Ishihara M, Suzuki S, Nakamura M, Enoki T, Fujiwara A, Hiura T, Homma K, Hoshino D, Hoshizaki K, Ida H, Ishida K, Itoh A, Kaneko T, Kubota K, Kuraji K, Kuramoto S, Makita A, Masaki T, Namikawa K, Niiyama K, Noguchi M, Nomiya H, Ohkubo T, Saito S, Sakai T, Sakimoto M, Sakio H, Shibano H, Sugita H, Suzuki M, Takashima A, Tanaka N, Tashiro N, Tokuchi N, Yakushima Forest Environment Conservation Center, Yoshida T, Yoshida Y (2011) Forest stand structure, composition, and dynamics in 34 sites over Japan. Ecol Res 26:1007-1008

Katsuyama M, Shibata H, Yoshioka T, Yoshida T, Ogawa A, Ohte N (2009) Applications of a hydro-biogeochemical model and long-term simulations of the effects of logging in forested watersheds. Sustain Sci 4:179-188

Kawanabe H (1996) Symbiosphere: the status quo on promotion of sciences for biodiversity. Gakujutu-Geppou 49:31-36

Kawanabe H, Ohgushi T, Higashi M (1993) Symbiosphere: Ecological complexity for promoting biodiversity. IUBS Special Issue 29, Biology International, the International Union of Biological Sciences News Magazine

Kim E-S (2006) Development, potentials, and challenges of the International Long-Term Ecological Research (ILTER) Network. Ecol Res 21:788-793

Kira T, Ono Y, Hosokawa T (1978) Biological production in a warm-temperate evergreen oak forest of Japan. JIBP Synthesis 18, University of Tokyo Press, Tokyo

Kohyama T, Urabe J, Hikosaka K, Shibata H, Yoshioka T, Konohira E, Murase J, Wada E (2007) Terrestrial ecosystems in monsoon Asia: scaling up from shoot module to watershed. In: Canadel J, Pataki D, Pitelka L (eds) Terrestrial ecosystems in a changing world. The IGBP Series. Springer, Berlin, pp 285-296

Lambin EF, Geist HJ (2006) Land-use and land-cover change: local processes and global impacts. In: The IGBP Series. Springer, Berlin

Larigauderie A, Prieur-Richard AH, Mace GM, Lonsdale M, Mooney HA, Brussaard L, Cooper D, Cramer W, Daszak P, Díaz S, Duraiappah A, Elmqvist T, Faith DP, Jackson LE, Krug C, Leadley PW, Le Prestre P, Matsuda H, Palmer M, Perrings C, Pulleman M, Reyers B, Rosa EA, Scholes RJ, Spehn E, Turner BL II, Yahara T (2012) Biodiversity and ecosystem services science for a sustainable planet: the DIVERSITAS vision for 2012-20. Curr Opin Environ Sustain 4:101-105

Lin YP, Hong NM, Wu PJ, Wu CF, Verburg PH (2007) Impacts of land use change scenarios on hydrology and land use pattern in the $\mathrm{Wu}-\mathrm{Tu}$ watershed in Northern Taiwan. Landsc Urban Plan $80: 111-126$

Lin YP, Lin YB, Wang YT, Hong NM (2008) Monitoring and predicting land-use changes and the hydrology of the urbanized Paochiao watershed in Taiwan using remote sensing data. Urban growth models and a hydrological model. Sensors 8:658-680

Lin YP, Verburg PH, Chang CR, Chen HY, Chen MH (2009) Developing and comparing optimal and empirical land-use models for the development of an urbanized watershed forest in Taiwan. Landsc Urban Plan 92:242-254

Lin YP, Wu CF, Chu HJ, Verburg PH (2011) Comparing the prediction abilities of logistic regression, auto-logistic regression and neural network models in empirical land-use change modeling. Int J Geogr Inf Sci 25:65-87

Liu W, Seto KC (2008) Using the ART-MMAP neural network to model and predict urban growth: a spatiotemporal data mining approach. Environ Plan B Plan Design 35:296-317

Loonen W, Heuberger P, Kuijpers-Lide M (2007) Spatial optimization in land-use allocation problems. In: Koomen E, Stillwell J, Bakema A, Scholten $\mathrm{H}$ (eds) Modelling land-use change. Springer, Netherlands, pp 147-165
Loreau M, Naeem S, Inchausti P, Bengtsson J, Grim JP, Hector A, Hooper DU, Huston MA, Raffaelli D, Schmid B, Tilman D, Wardle DA (2001) Biodiversity and ecosystem functioning: current knowledge and future challenges. Science 294:804-808

MA (2005) Millennium ecosystem assessment ecosystems and human well-being: the assessment series (four volumes and summary), Island Press, Washington DC

Matthews R, Gilbert N, Roach A, Polhill J, Gotts N (2007) Agentbased land-use models: a review of applications. Landsc Ecol 22:1447-1459

McCook LJ (1999) Macroalgae, nutrients, and phase shifts on coral reefs: scientific issues and management consequences for the Great Barrier Reef. Coral Reefs 18:357-367

Miki T (2009) A new graphical model for untangling complex relationship among environment, biodiversity, and ecosystem functioning. Ecol Res 24:937-941

Miki T (2012) Microbe-mediated plant-soil feedback and its roles in a changing world. Ecol Res 27:509-520

Miki T, Ushio M, Fukui S, Kondoh M (2010) Functional diversity of microbial decomposers facilitates plant coexistence in a plant-microbe-soil feedback model. Proc Natl Acad Sci USA 107:14251-14256

Miki T, Yokokawa T, Matsui K (2013) Biodiversity and multifunctionality in a microbial community: a novel theoretical approach to quantify functional redundancy. Proc Royal Soc Biol

Millennium Ecosystem Assessment (MA) (2005) Ecosystem and human well-being: synthesis. Island Press, Washington DC

Molino J-F, Sabatier D (2001) Tree diversity in tropical rain forests: a validation of the intermediate disturbance hypothesis. Science 294:1702-1704

Naeem S, Hahn DR, Schuurman G (2000) Producer-decomposer codependency influences biodiversity effects. Nature 403:762-764

Nagai S, Saigusa N, Muraoka H, Nasahara KN (2010) What makes the satellite-based EVI-GPP relationship unclear in a deciduous broad-leaved forest? Ecol Res 25:359-365

Naidoo R, Balmford A, Costanza R, Fisher B, Green RE, Lehner B, Malcolm TR, Ricketts TH (2008) Global mapping of ecosystem services and conservation priorities. Proc Natl Acad Sci USA 105:9495-9500

Nakano S, Murakami M (2001) Reciprocal subsidies: dynamic interdependence between terrestrial and aquatic food webs. Proc Natl Acad Sci USA 98:166-170

Nakano S, Yahara T, Nakashizuka T (2012) The biodiversity observation network in Asia-Pacific Region: toward further development of monitoring. Springer, Tokyo

Nakashizuka T (1991) The importance of long-term studies of forest dynamics in large plots. Jpn J Ecol 41:45-53 (in Japanese)

Nakashizuka T (2001) Ecological science and time scale. Kagaku (Science) 71:37-42 (in Japanese)

Nelson EJ, Daily G (2010) Modelling ecosystem services in terrestrial systems. Biol Rep 2:53

Nelson E, Mendoza G, Regetz J, Polasky S, Tallis H, Cameron DR, Chan KMA, Daily GC, Goldstein J, Kareiva PM, Lonsdorf E, Naidoo R, Ricketts TH, Shaw MR (2009) Modeling multiple ecosystem services, biodiversity conservation, commodity production, and tradeoffs at landscape scales. Front Ecol Environ 7:4-11

Ohte N, Nakaoka M, Shibata H (2012) ILTER and JaLTER: their missions and linkage to database development in the Asia-Pacific region. In: Nakano S, Yahara T, Nakashizuka T (eds) The biodiversity observation network in the Asia-Pacific region: toward further development of monitoring, Ecological Research Monographs, Springer Japan, Tokyo, pp 205-215

Okubo A, Sugiyama S (2009) Comparison of molecular fingerprinting methods for analysis of soil microbial community structure. Ecol Res 24:1399-1405

Parker DC, Manson SM, Janssen M, Hoffmann MJ, Deadman PJ (2003) Multi-agent systems for the simulation of land use and land cover change: a review. Ann Assoc Am Geogr 93:316-340

Pearson RG, Dawson TP (2003) Predicting the impacts of climate change on the distribution of species: are bioclimate envelope models useful? Global Ecol Biogeogr 12:361-371 
Pijanowski BC, Brown DG, Shellito BA, Manik GA (2002) Using neural networks and GIS to forecast land-use changes: land transformation model. Comput Environ Urban Syst 26:553-575

Pijanowski BC, Pithadia S, Shellito BA (2005) Calibrating a neural network-based urban change model for two metropolitan areas of the Upper Midwest of the United States. Int J Geogr Inf Sci 19:197-215

Polis GA, Hurd SD (1996) Linking marine and terrestrial food webs: allochthonous input from the ocean supports high secondary productivity on small islands and coastal land communities. Am Nat 147:396-423

Reich PB, Tilman D, Isbell F, Mueller K, Hobbie SE, Flynn DFB, Eisenhauer N (2012) Impacts of biodiversity loss escalate through time as redundancy fades. Science 336:589-592

Robinson DT, Brown DG, Parker DC, Schreinemachers P, Janssen MA, Huigen M, Wittmer H, Gotts N, Promburom P, Irwin E Berger T, Gatzweiler F, Barnaud C (2007) Comparison of empirical methods for building agent based models in land use science. J Land Use Sci 2:31-55

Sato H, Itoh A, Kohyama T (2007) SEIB-DGVM: a new dynamic global vegetation model using a spatially explicit individualbased approach. Ecol Model 24:279-307

Scheffer M, Carpenter SR (2003) Catastrophic regime shifts in ecosystems: linking theory to observation. Trends Ecol Evol 18:648-656

Shibata H, Bourgeron P (2011) Challenge of international longterm ecological research network (ILTER) for socio-ecological land sciences. GLP News 7:13-14

Shikita A, Koarai M (1997) Statistical analysis of artificial modification of natural coastline in Japan since 1960. J Jpn Assoc Coast Zone Stud 9:17-25

Takami H, Won N-I, Kawamura T (2013) Impacts of the 2011 mega-earthquake and tsunami on abalone Haliotis discus hannai and sea urchin Strongylocentrotus nudus populations at Oshika Peninsula, Miyagi, Japan. Fish Oceanogr 22:113-120

Tallis H, Polasky S (2009) Mapping and valuing ecosystem services as an approach for conservation and natural-resource management. Ann N Y Acad Sci 1162:265-283

Tallis HT, Ricketts T, Guerry AD, Nelson E, Ennaaanay D, Wolny S, Olwero N, Vigerstol K, Pennington D, Mendoza G, Aukema J, Foster J, Forrest J, Cameron D, Arekema K, Lonsdorf E, Kennedy C, Verutes G, Kim CK, Guannel G, Papenfus M, Toft J, Marsik M, Bernhardt J (2011) In VEST 2.0 beta user's guide. Integrated valuation of ecosystem services and tradeoffs. Natural Capital Project, Stanford, CA

The Ministry of the Environment (2013) Green reconstruction: Creating a new Sanriku Fukko (reconstruction) National Park. http://www.env.go.jp/jishin/park-sanriku/images/sanriku_fuk kou_project_eng.pdf

Tilman D (1980) A graphical-mechanistic approach to competition and predation. Am Nat 116:362-393

Troy A, Wilson MA (2006) Mapping ecosystem services: practical challenges and opportunities in linking GIS and value transfer. Ecol Econ 60:435-449
Urabe J, Suzuki T, Nishita T, Makino W (2013) Immediate ecological impacts of the 2011 Tohoku earthquake tsunami on intertidal flat communities. PLoS ONE 8:e62779. doi: 10.1371/journal.pone.0062779

Valbuena D, Verburg PH, Bregt AK, Ligtenberg A (2010) An agent-based approach to model land-use change at a regional scale. Landsc Ecol 25:185-199

Verburg PH, Veldkamp A (2004) Projecting land use transitions at forest fringes in the Philippines at two spatial scales. Landsc Ecol 19:77-98

Verburg PH, Soepboer W, Veldkamp A, Limpiada R, Espaldon V (2002) Modeling the spatial dynamics of regional land use: the CLUE-s model. Environ Manag 30:391-405

Vigerstol KL, Aukema JE (2011) A comparison of tools for modeling freshwater ecosystem services. J Environ Manag 92:2403-2409

Vihervaara P, D'Amato D, Forsius M, Angelstam P, Baessler C, Balvanera PB, Boldgiv, Bourgeron P, Dick J, Kanka R, Klotz $\mathrm{S}$, Maass M, Melecis V, Petř́k P, Shibata H, Tang J, Thompson J, Zacharias S (2013) Using long-term ecosystem service and biodiversity data to study the impacts and adaptation options in response to climate change: insights from the global ILTER sites network, Curr Opin Environ Sustain 5:53-66

Villa F, Ceroni M, Bagstad K, Johnson G, Krivovet S (2009) ARIES (Artificial Intelligence for Ecosystem Services): a new tool for ecosystem services assessment, planning, and valuation. 11 th international BIOECON conference on economic instruments to enhance the conservation and sustainable use of biodiversity. Venice, Italy. http://www.ucl.ac.uk/bioecon/11th_ 2009/Villa.pdf

Whanpetch N, Nakaoka M, Mukai H, Suzuki T, Nojima S, Kawai $\mathrm{T}$, Aryuthaka C (2010) Temporal changes in benthic communities of seagrass beds impacted by a tsunami in the Andaman Sea, Thailand. Est Coast Shelf Sci 87:246-252

Yahara T, Nakano S, Darnaedi D, Kim E-S, Ma K, Vergara S (2012) AP-BON (Asia-Pacific BON). GEO-BON Asilomar allhands meeting. Presentation material. http://www.earth observations.org/geobon_docs_20121203.shtml

Yamaji T, Sakai T, Endo T, Baruah PJ, Akiyama T, Saigusa N, Nakai Y, Kitamura K, Ishizuka M, Yasuoka Y (2008) Scalingup technique for net ecosystem productivity of deciduous broadleaved forests in Japan using MODIS data. Ecol Res $23: 765-775$

Yoshida T, Noguchi M (2009) Vulnerability to strong winds for major tree species in a northern Japanese mixed forest: analyses of historical data. Ecol Res 24:909-919

Yoshida T, Noguchi M, Akibayashi Y, Noda M, Kadomatsu M, Sasa K (2006) Twenty years of community dynamics in a mixed conifer-broad-leaved forest under a selection system in northern Japan. Can J For Res 36:1363-1375 